\title{
ЯКІСТЬ ЖИТТЯ ЖІНОК 3 ДЕПРЕСІЄЮ РІЗНОГО ГЕНЕЗУ ТА РІЗНОЇ ВИРАЖЕНОСТІ МАКРО-, МЕЗО- І МІКРОСОЦІАЛЬНОЇ ДЕЗАДАПТАЦІЇ
}

\author{
ВДНЗУ «Українська медична стоматологічна академія», м. Полтава, Україна
}

\begin{abstract}
Мета: вивчити якість життя жінок з депресією різного генезу та різної вираженості макро-, мезо- і мікросоціальної дезадаптації для визначення в подальшому таргетних мішеней персоніфікації лікувально-реабілітаційних заходів для цього контингенту пацієнтів.

Матеріали і методи. Обстежено 252 жінки $з$ депресивними розладами: 94 особи з психогенною (пролонгована депресивна реакція, зумовлена розладом адаптації), 83 жінки з ендогенною (депресивний епізод; рекурентний депресивний розлад; біполярний афективний розлад, поточний епізод депресії) і 75 пацієнток 3 органічною депресією (органічні афективні розлади). 48 жінок не мали ознак психосоціальної дезадаптації, у інших 204 встановлено прояви макро-, мезо- і мікросоціальної дезадаптації різної вираженості. Дослідження проводили 3 використанням клініко-психопатологічного та психодіагностичного методів.

Результати. Встановлено закономірності щодо погіршення якості життя за всіма ссрерами при зростанні тяжкості психосоціальної дезадаптації в усіх сорерах життєдіяльності. Найбільше ці закономірності проявляються при макросоціальній дезадаптації, а найменше - при мікросоціальній дезадаптації.

Висновки. Виявлено закономірності щодо погіршення якості життя за всіма сорерами при зростанні тяжкості психосоціальної дезадаптації в усіх сорерах життєдіяльності. Найбільше ці закономірності проявляються при макросоціальній, а найменше - при мікросоціальній дезадаптації.

Виявлені закономірності повинні враховувати при розробці лікувально-реабілітаційних заходів для хворих на депресивні розлади, що становить перспективу даної роботи.
\end{abstract}

КЛЮЧОВІ СЛОВА: депресивні розлади; психосоціальна дезадаптація; макро-; мезо-, мікросоціальна дезадаптація; психогенна депресія; органічна депресія; ендогенна депресія; жінки.

За визначенням ВООЗ [7], «якість життя (ЯЖ) це сприйняття людиною своєї позиції у житті, у тому числі фрізичного, психічного та соціального благополуччя, залежно від якості середовища, в якому вона живе, а також ступеня задоволення конкретним рівнем життя та іншими складовими психологічного комфорту».

ВООЗ рекомендує визначати Яж як індивідуальне співвідношення свого стану в житті суспільства в контексті культури та систем цінностей цього суспільства із завданням (бажаннями) конкретного індивідуума, його планами, можливостями та ступенем загального невлаштування [10]. Основними критеріями ЯЖ визначені: фрізичні (сила, енергія, втома, біль, дискомфорт, сон, відпочинок); психологічні (позитивні емоції, мислення, пам'ять, концентрація уваги, самооцінка, вигляд, негативні переживання); рівень самостійності (буденна активність, працездатність, залежність від лікування і ліків); суспільне життя (взаємини, суспільна цінність об'єкта, сексуальна активність); довколишнє середовище (благополуччя, безпека, побут, забезпеченість, якість і доступність медичного й соціального забезпечення, можливість освіти та підвищення кваліфрікації, дозвілля, екологія); духовність (релігія, особисті переконання) $[9,10]$.
На сьогодні ЯЖ розглядається як одна 3 ключових характеристик стану хворих з психічними розладами $[8,6]$, бо піддає оцінці фрізичні, психічні й соціальні аспекти життєдіяльності пацієнта та рівні його адаптації [1]. Ж. І. Матвієнко зазначає, що «для депресивного хворого оцінка його особистої Яж набуває величезного, а іноді й першорядного значення, тому даний інтегральний показник $€$ надзвичайно важливим у побудові цілісної та об'єктивної картини стану пацієнта» [5].

Мета роботи: вивчити ЯЖ жінок $з$ депресією різного генезу та різної вираженості макро-, мезо- і мікросоціальної дезадаптації для визначення в подальшому таргетних мішеней персоніфрікації лікувально-реабілітаційних заходів для цього контингенту пацієнтів.

Матеріали і методи. На базі Полтавського обласного психоневрологічного диспансеру й Полтавської обласної клінічної психіатричної лікарні імені О. Ф. Мальцева обстежено 252 жінки, яким був встановлений діагноз депресивного розладу відповідно до чинних нормативних документів. Згідно з дизайном роботи, в дослідження включено 94 особи 3 депресивним розладом психогенного генезу (пролонгована депресивна реакція, зумовлена розладом адаптації, код за MKX-10 F43.21), 83 жінки з ендогенною депресією 
(депресивний епізод, коди за МKX-10 F32.0, $\mathrm{F} 32.1, \mathrm{~F} 32.2, \mathrm{F32}, 3$; рекурентний депресивний розлад, коди за MKX-10 F33.0, F33.1, F33.2, F33.3; біполярний афективний розлад, поточний епізод депресії, коди за MKX-10 F31.3, F31.4, F31.5) та 75 пацієнток із депресивним розладом органічного генезу (органічні афективні розлади, код за MKX-10 F06.3) [2].

Для ідентифрікації та вимірювання вираженості психосоціальної дезадаптації (ПД) ми розробили оригінальну шкалу для комплексного оцінювання ступеня ПД у різних сорерах [3], яка охоплює три основних кластери психосоціального фрункціонування: макросоціальний, що включає оцінку соціально-економічної та соціально-інформаційної дезадаптації (МакПД); мезосоціальний, що включає оцінку соціально-професійної та міжособистісної дезадаптації (МезПД), та мікросоціальний, що включає оцінку сімейної та батьківської дезадаптації (МікПД). Ці шість сорер охоплюють основні напрямки психосоціальної адаптації (дезадаптації) і дозволяють визначити порушення психосоціального функціонування індивіда за всіма ключовими напрямками.

Обстежені жінки за результатами оцінювання ступеня ПД з використанням розробленої нами шкали були поділені на дві групи. До першої групи, кількістю 48 осіб, віднесені жінки, у яких за жодною зі сорер психосоціального фрункціонування показник не перевищував 19 балів, що відповідало відсутності ознак дезадаптації. До другої групи, кількістю 204 особи, віднесені жінки, у яких принаймні за однією зі шкал були виявлені показники понад 20 балів, що відповідає ознакам ПД. При цьому показник за шкалою в межах 20-29 балів розцінювали як ознаки ПД легкого ступеня, 30-39 балів - як ознаки ПД помірного ступеня, 40 і більше балів - ознаки ПД вираженого ступеня.

Таким чином, з урахуванням поєднання генезу депресії та ступеня МакПД, МезПД і МікПД виділено по 12 груп (рис. 1): пацієнтки з психогенною депресією та відсутністю ознак ПД (кількістю по 19 жінок у кожній), з ендогенною депресією та відсутністю ознак ПД (по 15 осіб у кожній), з органічною депресією та відсутністю ознак ПД (по 14 жінок у кожній); з психогенною депресією та ПД легкого ступеня (50, 57 та 25 жінок відповідно), 3 ендогенною депресією та ПД легкого ступеня (14, 16 і 5), з органічною депресією та ПД легкого ступеня (9, 13 і 2); з психогенною депресією та ПД помірного ступеня (16, 14 і 35), з ендогенною депресією та ПД помірного ступеня (37, 43 і 26), з органічною депресією та ПД помірного ступеня (18, 33 і 16); з психогенною депресією та ПД тяжкого ступеня (9, 4 і 15), з ендогенною депресією та ПД тяжкого ступеня (17, 9 і 36), з органічною депресією та ПД тяжкого ступеня (34, 15 і 44).

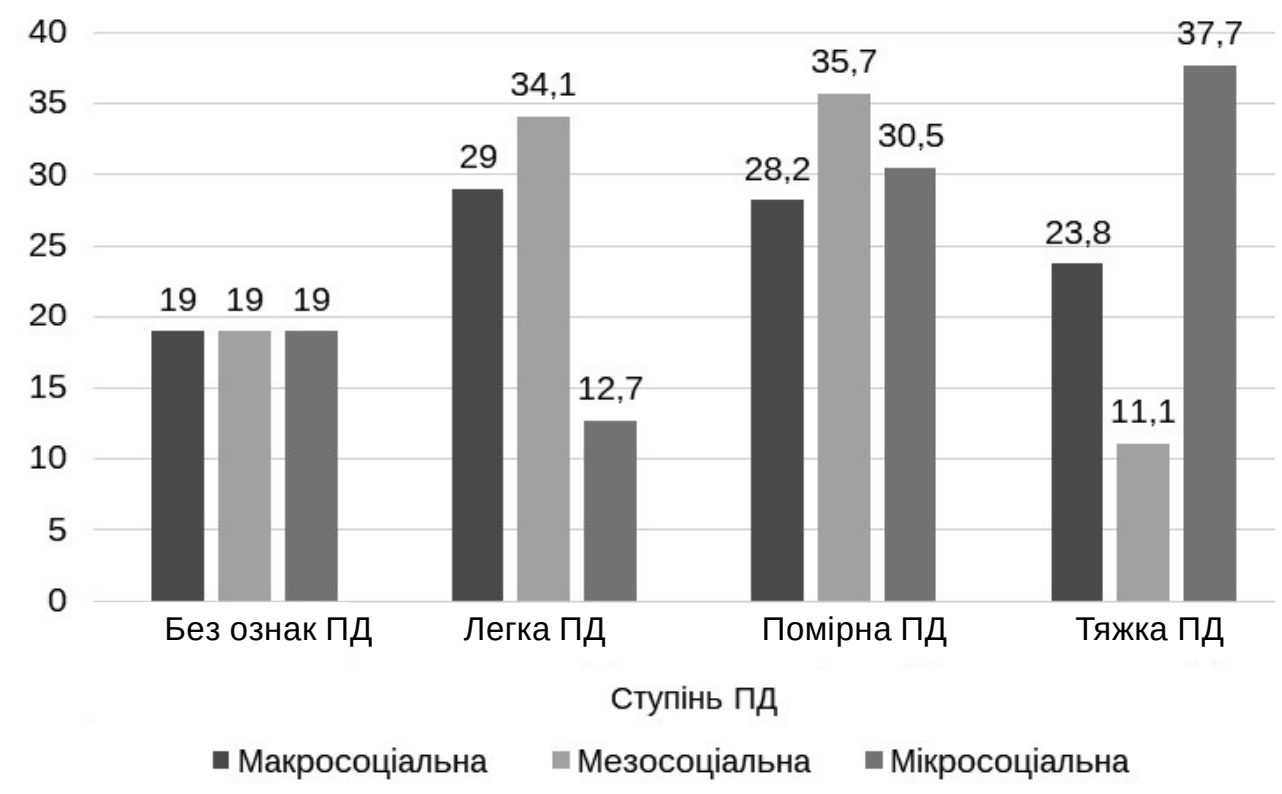

Puc. 1. Поділ обстежених за ступенем макро-, мезо- і мікросоціальної дезадаптації, \%.

ЯЖ пацієнток оцінювали за допомогою «Шкали оцінки якості життя» Н. Mezzich, N. Cohen, M. Ruiperez, I. Lin, G. Yoon в адаптації H. O. Maрути [4].

Статистико-математичний аналіз включав фрормування описової статистики та аналіз розбіжностей з використанням непараметричних методів: тесту Манна - Уїтні та точного критерію Фішера.

Результати дослідження та їх обговорення. Першим кроком роботи було здійснення аналізу особливостей ЯЖ у жінок, хворих на депресивні розлади, з різними ступенями МакПД. Середні показники ЯЖ за всіма сфрерами наведено у таблиці 1. 
Таблиця 1. Показники якості життя в жінок, хворих на депресивні розлади, з різними ступенями макросоціальної дезадаптації

\begin{tabular}{|c|c|c|c|c|c|c|c|c|c|c|}
\hline \multirow{2}{*}{ срера } & \multicolumn{4}{|c|}{ Ступінь МакПД } & \multirow[b]{2}{*}{$p_{1-2}$} & \multirow{2}{*}{$p_{1-3}$} & \multirow{2}{*}{$p_{1-4}$} & \multirow{2}{*}{$p_{2-3}$} & \multirow{2}{*}{$p_{2-4}$} & \multirow{2}{*}{$p_{3-4}$} \\
\hline & без ознак & легка & помірна & тяжка & & & & & & \\
\hline Фізичне благополуччя & $46 \pm 1,24$ & $4,12 \pm 1,08$ & $2,59 \pm 1,24$ & $1,72 \pm 0,96$ & $<0,05$ & $<0,01$ & $<0,01$ & $<0,01$ & $<0,01$ & $<0,01$ \\
\hline сихологі & & & $1,62 \pm 0,52$ & $1,55 \pm 0,50$ & $>0,05$ & $<0,01$ & $<0,01$ & $<0,01$ & $<0,01$ & $>0,05$ \\
\hline & $5,29 \pm 0,90$ & $4,55 \pm 0,87$ & $3,59 \pm 0,96$ & $2,62 \pm 1,04$ & $<0,01$ & $<0,01$ & $<0,01$ & $<0,01$ & $<0,01$ & $<0,01$ \\
\hline & & & & & 0,05 & 0,01 & D,01 & , ,01 & 0,01 & $<0,01$ \\
\hline & & $4,75 \pm 1,21$ & $3,68 \pm 1,48$ & & $<0,05$ & $<0,01$ & $<0,01$ & $<0,01$ & $<0,01$ & $<0,01$ \\
\hline & & L,57 & $\pm 2,03$ & & $>0,05$ & 0,01 & $<0,01$ & $<0,01$ & $<0,01$ & $<0,01$ \\
\hline Гроп & & & & & & & $<0,01$ & & & $<0,01$ \\
\hline стісна реалізація & & $1 \pm 1,15$ & $52 \pm 1,14$ & 0,94 & 0,01 & 0,01 & 0,01 & $<0,01$ & $<0,01$ & $<0,01$ \\
\hline & & $5,66=$ & & & $>0,05$ & $<0,01$ & $<0,01$ & $<0,01$ & $<0,01$ & $<0,01$ \\
\hline $\begin{array}{l}\text { Зага } \\
\text { житт }\end{array}$ & $2,85 \pm 1,03$ & $2,37 \pm 0,83$ & $1,73 \pm 0,56$ & $1,55 \pm 0,50$ & $<0,05$ & $<0,01 \mid$ & $<0,01$ & $<0,01$ & $<0,01$ & $>0,05$ \\
\hline & $8,56 \pm 2,62$ & $8,49 \pm 1,97$ & $5,89 \pm 1,81$ & $4,82 \pm 1,49$ & $>0,05$ & $<0,01$ & $<0,01$ & $<0,01$ & $<0,01$ & $<0,01$ \\
\hline & & $16,08 \pm 3,21$ & $12,08 \pm 3,69$ & & $<0,05$ & $<0,01$ & $<0,01$ & $<0,01$ & $<0,01$ & $<0,01$ \\
\hline Зовнішні життєві умови & 4,72 & $19,53 \pm 3,02$ & $14,30 \pm 4,64$ & $10,17 \pm 4,37$ & $>0,05$ & $<0,01$ & $<0,01$ & $<0,01$ & $<0,01$ & $<0,01$ \\
\hline Сума & 45,42 & $44,11 \pm 7,36$ & $32,27 \pm 9,19$ & $23,82 \pm 8,24$ & $>0,05$ & $<0,01$ & $<0,01$ & $<0,01$ & $<0,01$ & $<0,01$ \\
\hline Показник якості життя & $4,54 \pm 1,19$ & $4,41 \pm 0,74$ & $3,23 \pm 0,92$ & $2,38 \pm 0,82$ & $>0,05$ & $<0,01$ & $<0,01$ & $<0,01$ & $<0,01$ & $<0,01$ \\
\hline
\end{tabular}

Аналіз показників свідчив про наявність чіткої тенденції до погіршення показників ЯЖ за всіма ключовими сорерами по мірі зростання МакПД, причому найвираженіші відмінності виявлені між групами з легкою та помірною МакПД (рис. 2).

Так, середнє значення показника фрізичного благополуччя у жінок без ознак МакПД склало $(4,46 \pm 1,24)$ бала, 3 ознаками МакПД легкого ступеня - $(4,12 \pm 1,08)$ бала, 3 ознаками МакПД помірного ступеня - $(2,59 \pm 1,24)$ бала, 3 ознаками МакПД тяжкого ступеня - $(1,72 \pm 0,96)$ бала; психологічного (емоційного) благополуччя відповідно, $(2,27 \pm 0,82)$ бала, $(2,10 \pm 0,69)$ бала, $(1,62 \pm 0,52)$ бала і $(1,55 \pm 0,50)$ бала; самообслуговування і незалежності дій - відповідно, $(5,29 \pm 0,90)$ бала, $(4,55 \pm 0,87)$ бала, $(3,59 \pm 0,96)$ бала і $(2,62 \pm 1,04)$ бала; працездатності-відповідно, $(3,44 \pm 1,27)$ бала, $(3,45 \pm 0,96)$ бала, $(2,35 \pm 1,00)$ бала і $(1,77 \pm 0,91)$ бала; міжособистісної взаємодії - відповідно, $(4,81 \pm 2,00)$ бала, $(4,75 \pm 1,21)$ бала, $(3,68 \pm 1,48)$ бала і $(2,65 \pm 1,29)$ бала; соціально-емоційної підтримки - відповідно, $(6,54 \pm 1,89)$ бала, $(6,41 \pm 1,57)$ бала, $(4,24 \pm 2,03)$ бала і $(2,75 \pm 1,85)$ бала; громадської та службової підтримки - відповідно, $(7,58 \pm 1,57)$ бала, $(7,49 \pm 1,06)$ бала, $(5,65 \pm 1,51)$ бала і $(4,43 \pm 1,56)$ бала; особистісної реалізації відповідно, $(4,33 \pm 1,24)$ бала, $(3,41 \pm 1,15)$ бала, $(2,52 \pm 1,14)$ бала і $(1,80 \pm 0,94)$ бала; духовної реалізації - відповідно, $(5,52 \pm 1,91)$ бала,
$(5,66 \pm 1,11)$ бала, $(4,35 \pm 1,67)$ бала і $(2,98 \pm$ $1,50)$ бала; загального сприйняття життя - відповідно, $(2,85 \pm 1,03)$ бала, $(2,37 \pm 0,83)$ бала, $(1,73 \pm 0,56)$ бала і $(1,55 \pm 0,50)$ бала.

Аналіз інтегральних показників за всіма сорерами також виявив значущі відмінності у показниках ЯЖ у хворих із різними ступенями МакПД, найвираженіші між групами хворих із легкою та помірною МакПД (рис. 3). Середнє значення показника за сферою суб'єктивного благополуччя/ задоволеності у жінок без ознак МакПД склало $(8,56 \pm 2,62)$ бала, 3 ознаками МакПД легкого ступеня - $(8,49 \pm 1,97)$ бала, 3 ознаками МакПд помірного ступеня - $(5,89 \pm 1,81)$ бала, 3 ознаками МакПД тяжкого ступеня - $(4,82 \pm 1,49)$ бала; за сферою виконання соціальних ролей - відповідно, $(17,17 \pm 4,93)$ бала, $(16,08 \pm 3,21)$ бала, $(12,08 \pm 3,69)$ бала і $(8,83 \pm 3,07)$ бала; за ссрерою зовнішніх життєвих умов - відповідно, $(19,69 \pm 4,72)$ бала, $(19,53 \pm 3,02)$ бала, $(14,30 \pm 4,64)$ бала і $(10,17 \pm 4,37)$ бала.

Загальна сума балів за шкалою якості життя у жінок без ознак МакПД склала $(45,42 \pm 11,86)$ бала, 3 ознаками МакПД легкого ступеня $(44,11 \pm 7,36)$ бала, 3 ознаками МакПД помірного ступеня - $(32,27 \pm 9,19)$ бала, з ознаками МакПд тяжкого ступеня - $(23,82 \pm 8,24)$ бала; показник яЖ-відповідно, $(4,54 \pm 1,19)$ бала, $(4,41 \pm 0,74)$ бала, $(3,23 \pm 0,92)$ бала і $(2,38 \pm 0,82)$ бала. 
Загальне сприйняття життя

Духовна реалізація

Особистісна реалізація

Громадська і службова підтримка

Міжособистісна взаємодія

Соціально-емоційна
підтримка

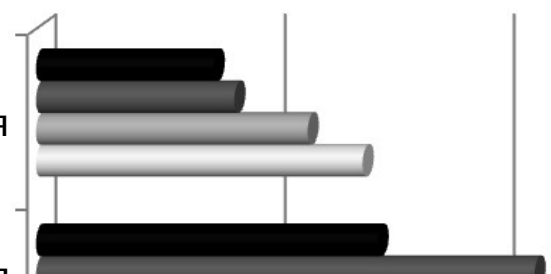

| 


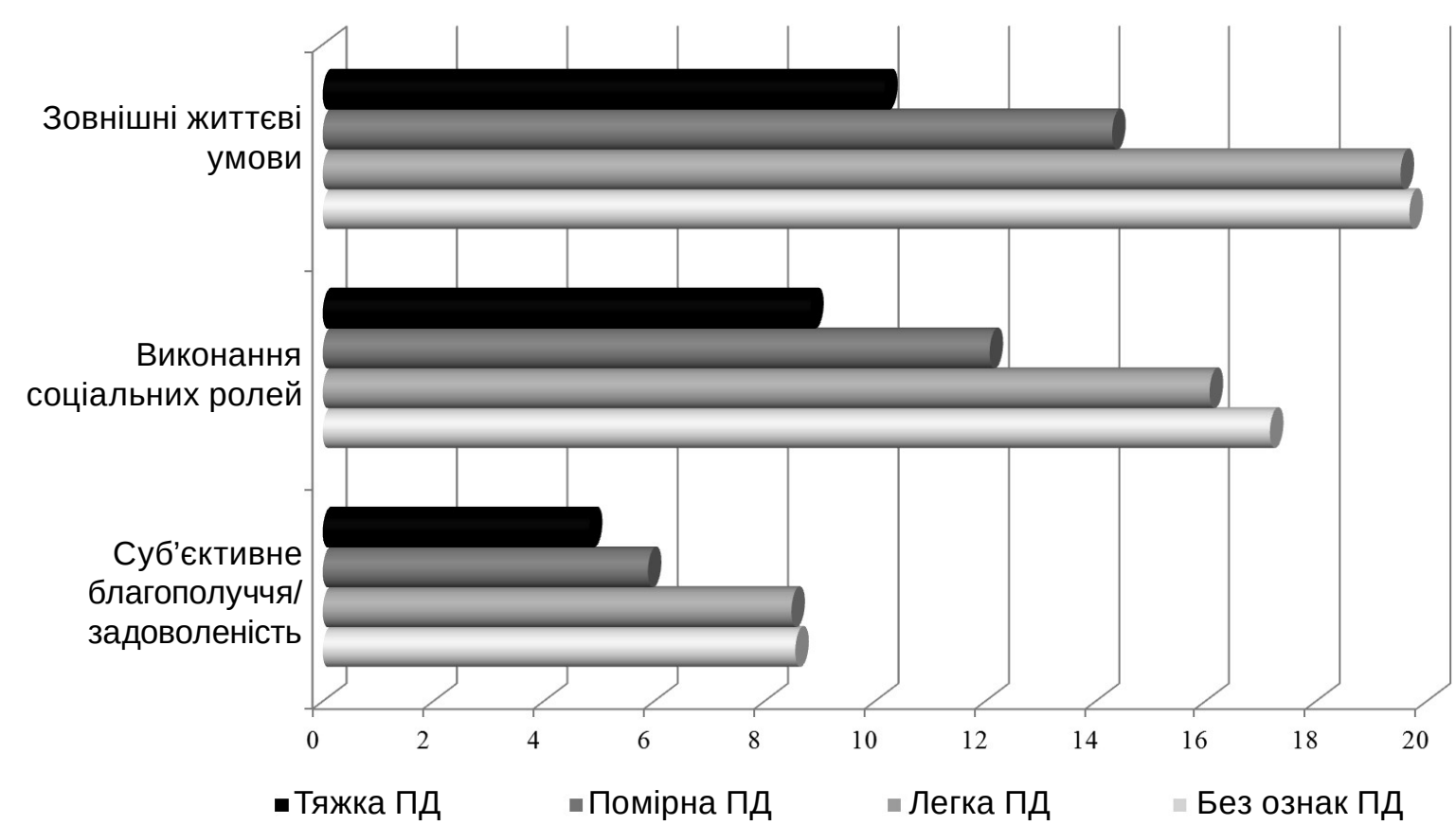

Puc. 3. Середні показники за основними сферами якості життя у жінок, хворих на депресивні розлади, з різними ступенями макросоціальної дезадаптації.

Таблиця 2. Показники якості життя у жінок, хворих на депресивні розлади, з різними ступенями мезосоціальної дезадаптації

\begin{tabular}{|c|c|c|c|c|c|c|c|c|c|c|}
\hline \multirow{2}{*}{ Copepa } & \multicolumn{4}{|c|}{ Ступінь МезПД } & \multirow{2}{*}{$\mathrm{p}_{1-2}$} & \multirow{2}{*}{$p_{1-3}$} & \multirow{2}{*}{$p_{1-4}$} & \multirow{2}{*}{$p_{2-3}$} & \multirow{2}{*}{$p_{2-4}$} & \multirow{2}{*}{$p_{3-4}$} \\
\hline & без ознак & легка & помірна & тяжка & & & & & & \\
\hline $\begin{array}{l}\text { Фізичне } \\
\text { благополуччя }\end{array}$ & $4,46 \pm 1,24$ & $3,95 \pm 1,15$ & $2,38 \pm 1,20$ & $1,21 \pm 0,50$ & $<0,01$ & $<0,01$ & $<0,01$ & $<0,01$ & $<0,01$ & $<0,01$ \\
\hline $\begin{array}{l}\text { Психологічне } \\
\text { (емоційне) } \\
\text { благополуччя }\end{array}$ & $2,27 \pm 0,82$ & $2,01 \pm 0,69$ & $1,64 \pm 0,50$ & $1,43 \pm 0,50$ & $>0,05$ & $<0,01$ & $<0,01$ & $<0,01$ & $<0,01$ & $>0,05$ \\
\hline $\begin{array}{l}\text { Самообслуговування } \\
\text { і незалежність дій }\end{array}$ & $5,29 \pm 0,90$ & $4,48 \pm 0,86$ & $3,23 \pm 1,07$ & $2,43 \pm 0,96$ & $<0,01$ & $<0,01$ & $<0,01$ & $<0,01$ & $<0,01$ & $<0,01$ \\
\hline Працездатність & $3,44 \pm 1,27$ & $3,33 \pm 1,01$ & $2,28 \pm 0,96$ & $1,21 \pm 0,50$ & $>0,05$ & $<0,01$ & $<0,01$ & $<0,01$ & $<0,01$ & $<0,01$ \\
\hline $\begin{array}{l}\text { Міжособистісна } \\
\text { взаємодія }\end{array}$ & $4,81 \pm 2,00$ & $4,71 \pm 1,26$ & $3,39 \pm 1,35$ & $2,04 \pm 1,10$ & $<0,05$ & $<0,01$ & $<0,01$ & $<0,01$ & $<0,01$ & $<0,01$ \\
\hline $\begin{array}{l}\text { Соціально-емоційна } \\
\text { підтримка }\end{array}$ & $6,54 \pm 1,89$ & $6,15 \pm 1,73$ & $3,99 \pm 1,99$ & $1,64 \pm 1,03$ & $>0,05$ & $<0,01$ & $<0,01$ & $<0,01$ & $<0,01$ & $<0,01$ \\
\hline $\begin{array}{l}\text { Громадська і } \\
\text { службова підтримка }\end{array}$ & $7,58 \pm 1,57$ & $7,23 \pm 1,29$ & $5,39 \pm 1,58$ & $3,82 \pm 1,22$ & $<0,05$ & $<0,01$ & $<0,01$ & $<0,01$ & $<0,01$ & $<0,01$ \\
\hline $\begin{array}{l}\text { Особистісна } \\
\text { реалізація }\end{array}$ & $4,33 \pm 1,24$ & $3,37 \pm 1,23$ & $2,22 \pm 0,99$ & $1,64 \pm 0,87$ & $<0,01$ & $<0,01$ & $<0,01$ & $<0,01$ & $<0,01$ & 0,004 \\
\hline Духовна реалізація & $5,52 \pm 1,91$ & $5,48 \pm 1,26$ & $4,04 \pm 1,68$ & $2,36 \pm 1,16$ & $>0,05$ & $<0,01$ & $<0,01$ & $<0,01$ & $<0,01$ & $<0,01$ \\
\hline $\begin{array}{l}\text { Загальне сприйняття } \\
\text { життя }\end{array}$ & $2,85 \pm 1,03$ & $2,27 \pm 0,82$ & $1,71 \pm 0,55$ & $1,43 \pm 0,50$ & $<0,01$ & $<0,01$ & $<0,01$ & $<0,01$ & $<0,01$ & $<0,05$ \\
\hline $\begin{array}{l}\text { Суб'єктивне } \\
\text { благополуччя/ } \\
\text { задоволеність }\end{array}$ & $8,56 \pm 2,62$ & $8,13 \pm 2,15$ & $5,71 \pm 1,64$ & $4,07 \pm 1,27$ & $>0,05$ & $<0,01$ & $<0,01$ & $<0,01$ & $<0,01$ & $<0,01$ \\
\hline $\begin{array}{l}\text { Виконання } \\
\text { соціальних ролей }\end{array}$ & $17,17 \pm 4,93$ & $15,79 \pm 3,44$ & $11,10 \pm 3,29$ & $7,32 \pm 2,55$ & $<0,05$ & $<0,01$ & $<0,01$ & $<0,01$ & $<0,01$ & $<0,01$ \\
\hline $\begin{array}{l}\text { Зовнішні життєві } \\
\text { умови }\end{array}$ & $19,69 \pm 4,72$ & $18,86 \pm 3,60$ & $13,44 \pm 4,70$ & $7,82 \pm 2,86$ & $>0,05$ & $<0,01$ & $<0,01$ & $<0,01$ & $<0,01$ & $<0,01$ \\
\hline Сума балів & $45,42 \pm 11,86$ & $42,78 \pm 8,28$ & $30,26 \pm 8,86$ & $19,21 \pm 5,72$ & $<0,05$ & $<0,01$ & $<0,01$ & $<0,01$ & $<0,01$ & $<0,01$ \\
\hline Показник якості життя & $4,54 \pm 1,19$ & $4,28 \pm 0,83$ & $3,03 \pm 0,89$ & $1,92 \pm 0,57$ & $<0,05$ & $<0,01$ & $<0,01$ & $<0,01$ & $<0,01$ & $<0,01$ \\
\hline
\end{tabular}




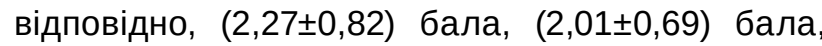
$(1,64 \pm 0,50)$ бала і $(1,43 \pm 0,50)$ бала; самообслуговування і незалежності дій - відповідно, $(5,29 \pm 0,90)$ бала, $(4,48 \pm 0,86)$ бала, $(3,23 \pm 1,07)$ бала і $(2,43 \pm 0,96)$ бала; працездатності - відповідно, $(3,44 \pm 1,27)$ бала, $(3,33 \pm 1,01)$ бала, $(2,28 \pm 0,96)$ бала і $(1,21 \pm 0,50)$ бала; міжособистісної взаємодії - відповідно, $(4,81 \pm 2,00)$ бала, $(4,71 \pm 1,26)$ бала, $(3,39 \pm 1,35)$ бала і $(2,04 \pm 1,10)$ бала; соціально-емоційної підтримки - відпо-

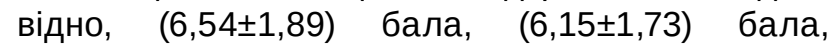

$(3,99 \pm 1,99)$ бала і $(1,64 \pm 1,03)$ бала; громадської та службової підтримки - відповідно, $(7,58 \pm 1,57)$ бала, $(7,23 \pm 1,29)$ бала, $(5,39 \pm 1,58)$ бала і $(3,82 \pm 1,22)$ бала; особистісної реалізації - від-

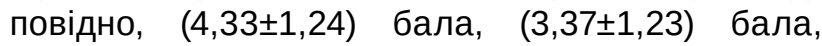
$(2,22 \pm 0,99)$ бала і $(1,64 \pm 0,87)$ бала; духовної реалізації - відповідно, $(5,52 \pm 1,91)$ бала, $(5,48 \pm 1,26)$ бала, бала i $(2,36 \pm 1,16)$ бала; загального сприйняття життя -

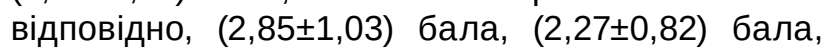
$(1,71 \pm 0,55)$ бала і $(1,43 \pm 0,50)$ бала (рис. 4$)$.

Загальне сприйняття життя

Духовна реалізація

Особистісна реалізація

Громадська і службова підтримка

Соціально-емоційна
підтримка

Міжособистісна взаємодія

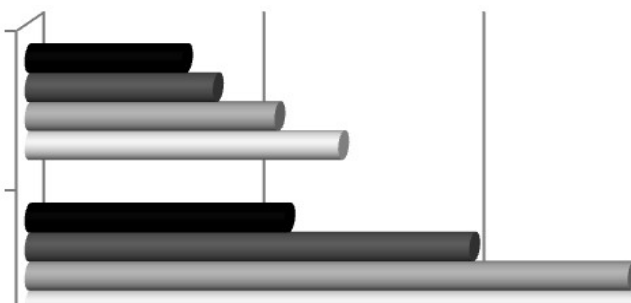

Працездатність

Самообслуговування
і незалежність дій

Психологічне (емоційне) благополуччя

Фізичне благополуччя
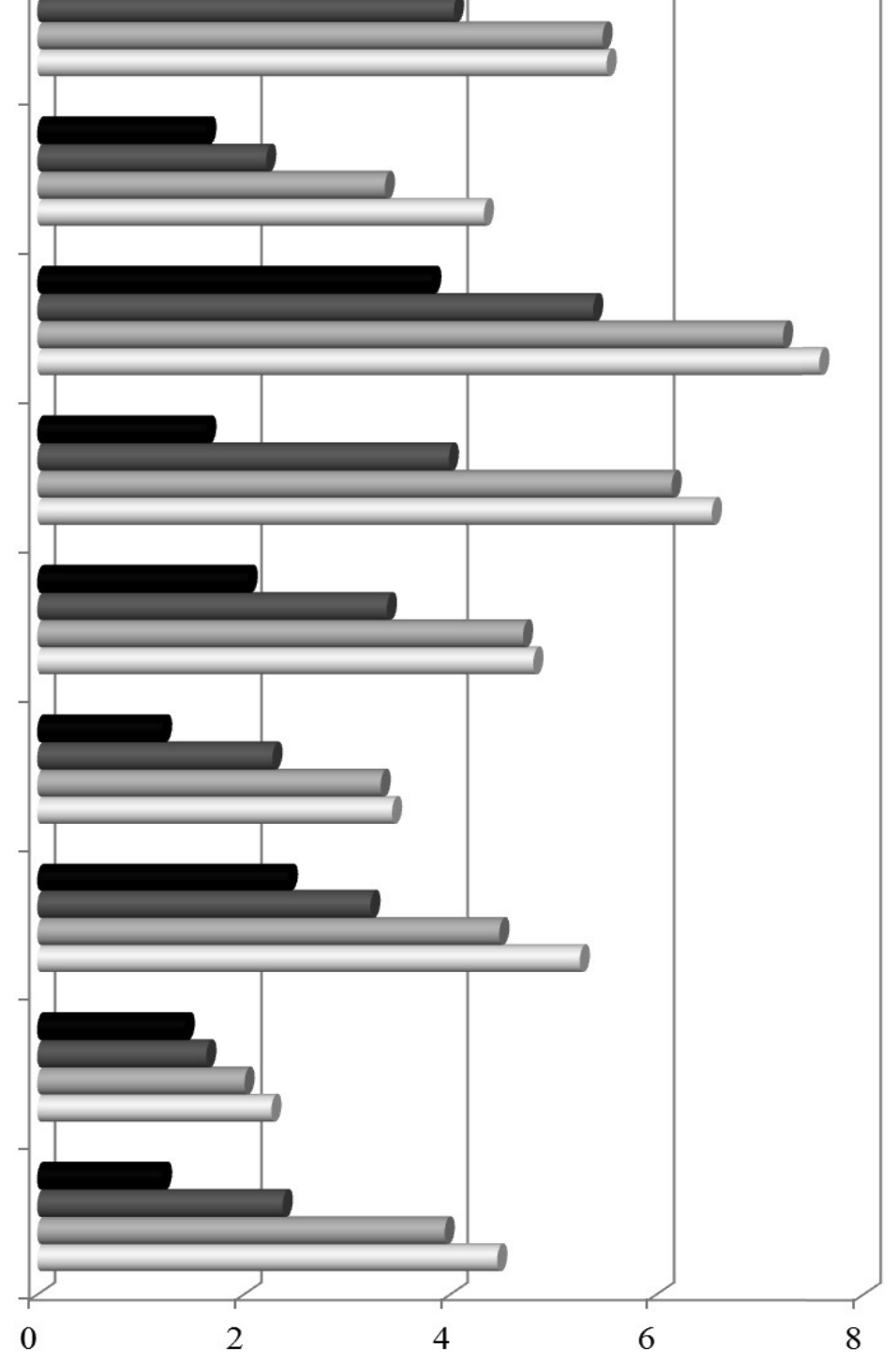

Середній показник, бали
Тяжка ПД
- Помірна ПД
- Легка Пд
- Без ознак ПД

Рuc. 4. Середні показники якості життя у жінок, хворих на депресивні розлади, з різними ступенями мезосоціальної дезадаптації. 
Підсумкові показники за основними сорерами ЯЖ також зменшувалися по мірі зростання ознак МезПД (рис. 5). Так, середнє значення показника за сорерою суб'єктивного благополуччя/задоволеності у жінок без ознак МезПД склало $(8,56 \pm 2,62)$ бала, з ознаками МезПД легкого ступеня - $(8,13 \pm 2,15)$ бала, 3 ознаками МезПД помірного ступеня $(5,71 \pm 1,64)$ бала, 3 ознаками МезПД тяжкого ступеня - $(4,07 \pm 1,27)$ бала; за сорерою виконання соціальних ролей - відповідно, $(17,17 \pm 4,93)$ бала, $(15,79 \pm 3,44)$ бала, $(11,10 \pm 3,29)$ бала і $(7,32 \pm$ $2,55)$ бала; за сорерою зовнішніх життєвих умов -

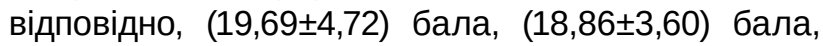
$(13,44 \pm 4,70)$ бала і $(7,82 \pm 2,86)$ бала.

Загальна сума балів за шкалою якості життя у жінок без ознак МезПД склала $(45,42 \pm 11,86)$ бала,

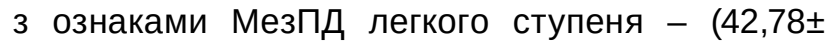
$8,28)$ бала, з ознаками МезПД помірного ступеня - $(30,26 \pm 8,86)$ бала, з ознаками МезПД тяжкого ступеня - $(19,21 \pm 5,72)$ бала; показник ЯЖ відповідно, $(4,54 \pm 1,19)$ бала, $(4,28 \pm 0,83)$ бала, $(3,03 \pm 0,89)$ бала і $(1,92 \pm 0,57)$ бала.

При аналізі особливостей ЯЖ при різних ступенях МікПД виявлено зменшення показників яж при зростанні ознак МікПД, при цьому найменш вираженими є відмінності між хворими без ознак МікПД, а найбільш вираженими - між хворими 3 легкою та помірною МікПД (табл. 3).

Середнє значення показника фрізичного благополуччя у жінок без ознак МікПД склало $(4,46 \pm 1,24)$ бала, 3 ознаками МікПД легкого ступеня - $(4,38 \pm 1,01)$ бала, 3 ознаками МікПД помірного ступеня - $(3,36 \pm 1,30)$ бала, 3 ознаками МікПД тяжкого ступеня - $(1,99 \pm 1,13)$ бала; психологічного (емоційного) благополуччя -

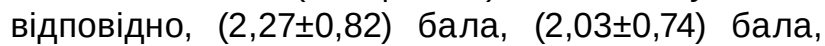
$(1,84 \pm 0,67)$ бала і $(1,62 \pm 0,51)$ бала; самообслуговування і незалежності дій - відповідно, $(5,29 \pm 0,90)$ бала, $(4,66 \pm 0,97)$ бала, $(4,13 \pm 0,95)$ бала і $(2,92 \pm 1,07)$ бала; працездатності - відповідно, $(3,44 \pm 1,27)$ бала, $(3,66 \pm 0,90)$ бала, $(2,96 \pm 1,06)$ бала і $(1,89 \pm 0,93)$ бала; міжособистісної взаємодії - відповідно, $(4,81 \pm 2,00)$ бала, $(4,94 \pm 1,11)$ бала, $(4,21 \pm 1,44)$ бала і $(3,00 \pm 1,43)$ бала; соціально-емоційної підтримки-відповідно, $(6,54 \pm 1,89)$ бала, $(6,50 \pm 1,55)$ бала, $(5,49 \pm 2,04)$ бала і $(3,19 \pm 1,97)$ бала; громадської і службової підтримки - відповідно, $(7,58 \pm 1,57)$ бала, $(7,91 \pm 1,12)$ бала, $(6,45 \pm 1,44)$ бала і $(4,88 \pm 1,65)$ бала; особистісної реалізації - відповідно, $(4,33 \pm 1,24)$ бала, $(3,69 \pm 1,15)$ бала, $(2,91 \pm 1,22)$ бала і $(2,04 \pm 1,02)$ бала; духовної реалізації - відповідно, $(5,52 \pm 1,91)$ бала, $(5,94 \pm 1,19)$ бала, $(4,96 \pm 1,45)$ бала і $(3,46 \pm 1,67)$ бала; загального сприйняття життя -

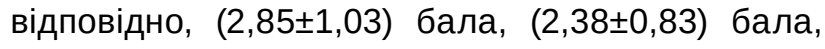
$(2,01 \pm 0,79)$ бала і $(1,66 \pm 0,56)$ бала (рис. 6$)$.

Аналіз сумарних показників за різними сорерами ЯЖ також виявив тенденцію до погіршення показників по мірі зростання ознак МікПД (рис. 7). Так, середнє значення показника за сорерою суб'єктивного благополуччя/ задоволеності у жінок без ознак МікПД склало $(8,56 \pm 2,62)$ бала, з ознаками МікПД легкого

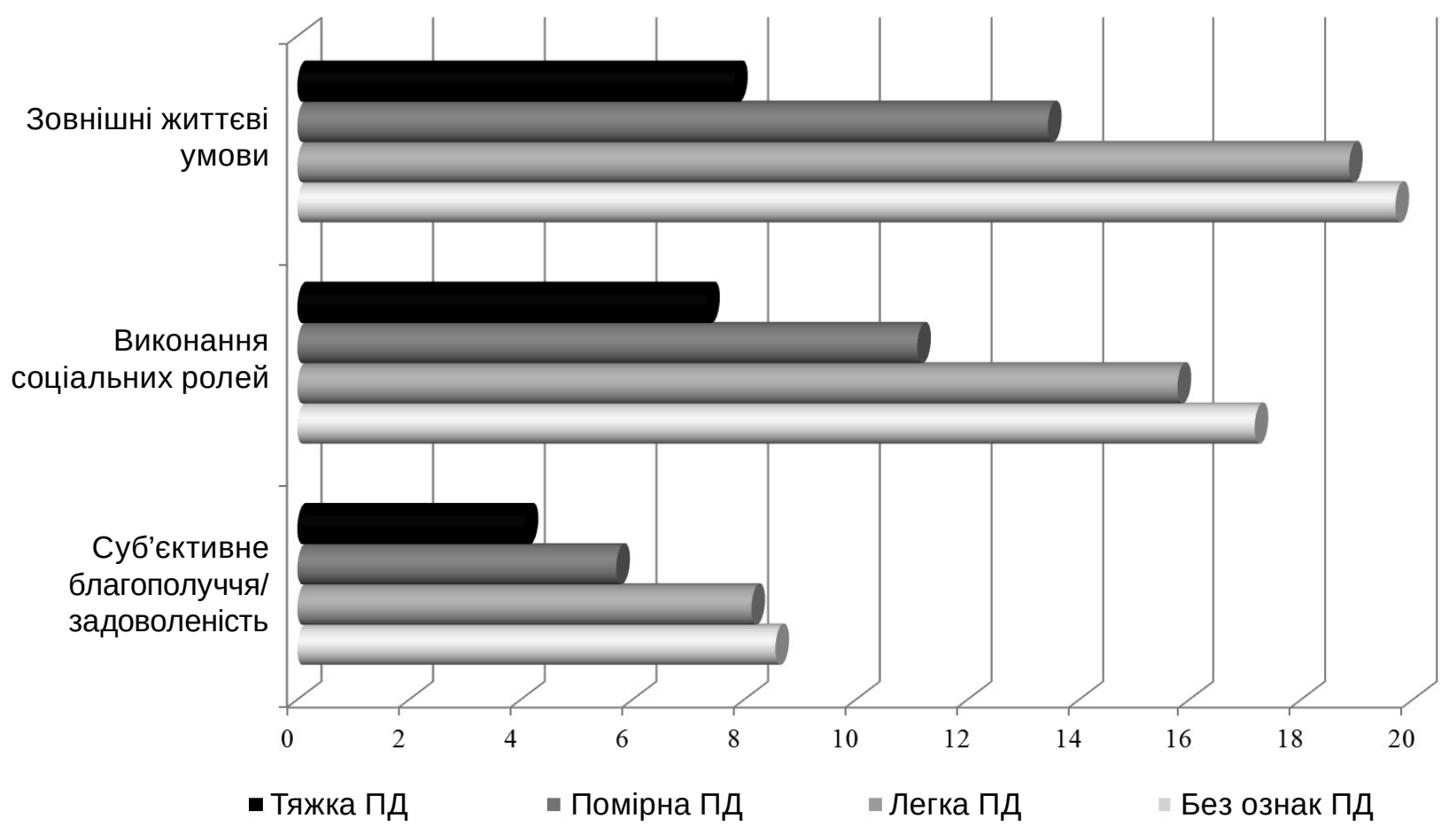

Puc. 5. Середні показники за основними сферами якості життя у жінок, хворих на депресивні розлади, з різними ступенями мезосоціальної дезадаптації. 
Загальне сприйняття життя

Духовна реалізація

Особистісна реалізація

Громадська і службова

підтримка

Соціально-емоційна підтримка

Міжособистісна взаємодія

Самообслуговування
і незалежність дій
Психологічне (емоційне)
благополуччя

Фізичне благополуччя

Працездатність

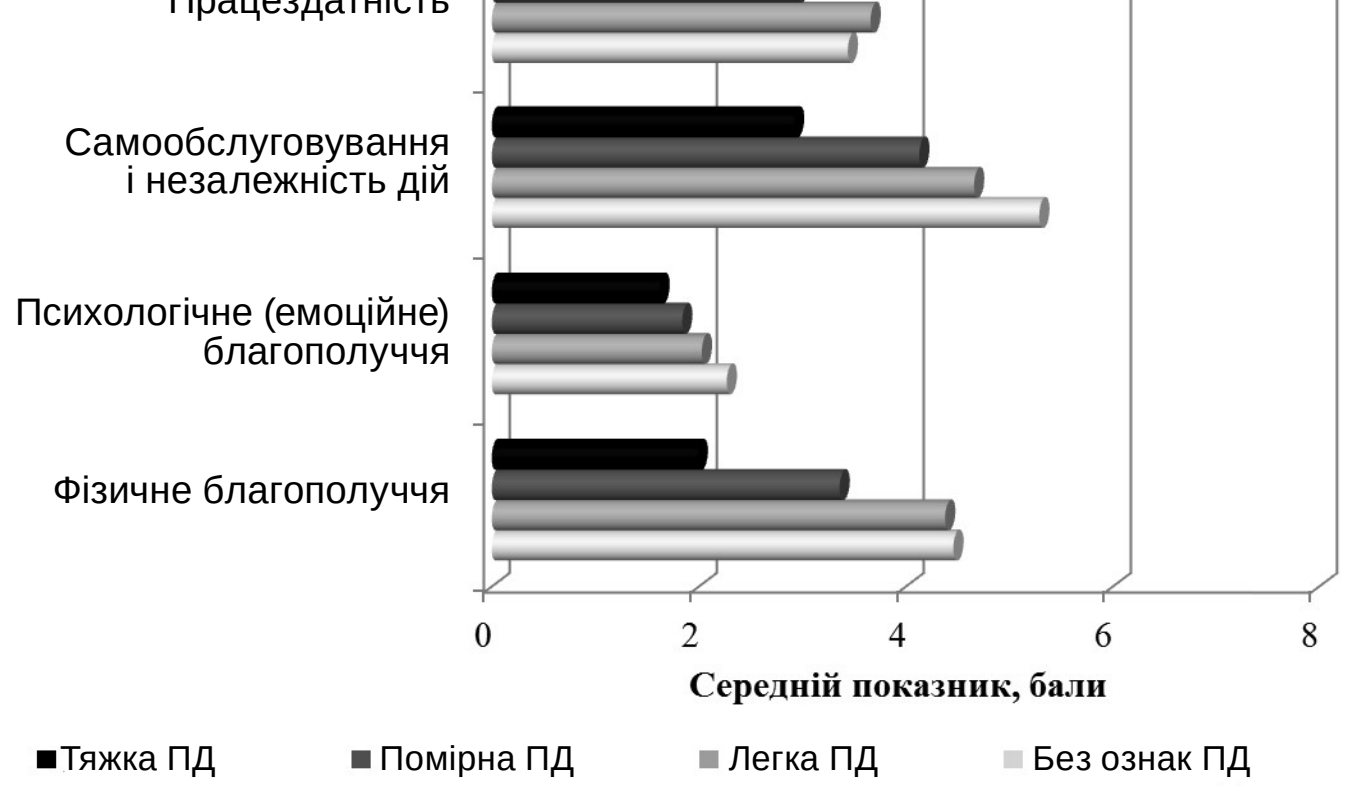

Рuc. 6. Середні показники якості життя у жінок, хворих на депресивні розлади, з різними ступенями мікросоціальної дезадаптації.

ступеня - $(8,75 \pm 2,09)$ бала, з ознаками МікПд помірного ступеня - $(7,09 \pm 2,28)$ бала, 3 ознаками МікПД тяжкого ступеня - $(5,27 \pm 1,67)$ бала; за сорерою виконання соціальних ролей - від-

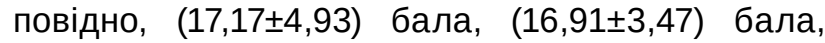
$(14,09 \pm 3,64)$ бала і $(9,85 \pm 3,49)$ бала; за сорерою зовнішніх життєвих умов - відповідно, $(19,69 \pm 4,72)$ бала, $(20,34 \pm 3,10)$ бала, $(16,94 \pm$ $4,27)$ бала і $(11,54 \pm 4,84)$ бала.
Загальна сума балів за шкалою якості життя у жінок без ознак МікПД склала $(45,42 \pm 11,86)$ бала, 3 ознаками МікПД легкого ступеня $(46,00 \pm 7,90)$ бала, з ознаками МікПД помірного ступеня - $(38,12 \pm 9,28)$ бала, з ознаками МікПД тяжкого ступеня - $(26,66 \pm 9,34)$ бала; показник ЯЖ - відповідно, $(4,54 \pm 1,19)$ бала, $(4,60 \pm 0,79)$ бала, $(3,81 \pm 0,93)$ бала і $(2,67 \pm 0,93)$ бала. 
Таблиця 3. Показники якості життя у жінок, хворих на депресивні розлади, з різними ступенями мікросоціальної дезадаптації

\begin{tabular}{|c|c|c|c|c|c|c|c|c|c|c|}
\hline \multirow{2}{*}{ Сорера } & \multicolumn{4}{|c|}{ Ступінь МікПД } & \multirow[b]{2}{*}{$p_{1-2}$} & \multirow[b]{2}{*}{$p_{1-3}$} & \multirow[b]{2}{*}{$p_{1-4}$} & \multirow[b]{2}{*}{$p_{2-3}$} & \multirow[b]{2}{*}{$p_{2-4}$} & \multirow[b]{2}{*}{$p_{3-4}$} \\
\hline & без ознак & легка & помірна & тяжка & & & & & & \\
\hline Фізичне благополуччя & $4,46 \pm 1,24$ & $4,38 \pm 1,01$ & $3,36 \pm 1,30$ & $1,99 \pm 1,13$ & $>0,05$ & $<0,01$ & $<0,01$ & $<0,01$ & $<0,01$ & $<0,01$ \\
\hline $\begin{array}{l}\text { Психологічне } \\
\text { (емоційне) } \\
\text { благополуччя }\end{array}$ & $2,27 \pm 0,82$ & $2,03 \pm 0,74$ & $1,84 \pm 0,67$ & $1,62 \pm 0,51$ & $>0,05$ & $<0,01$ & $<0,01$ & $>0,05$ & $<0,01$ & $<0,05$ \\
\hline $\begin{array}{l}\text { Самообслугову } \\
\text { незалежність д }\end{array}$ &, 90 & $4,66 \pm 0,97$ & $4,13 \pm 0,95$ & $2,92 \pm 1,07$ & $<0,01$ & $<0,01$ & $<0,01$ & $<0,05$ & $<0,01$ & $<0,01$ \\
\hline Працездат & 27 & $3,66 \pm 0,90$ & $2,96 \pm 1,06$ & $1,89 \pm 0,93$ & $>0,05$ & $<0,05$ & $<0,01$ & $<0,01$ & $<0,01$ & $<0,01$ \\
\hline $\begin{array}{l}\text { Міжособистісна } \\
\text { взаємодія }\end{array}$ & $4,81 \pm 2,00$ & $4,94 \pm 1,11$ & $4,21 \pm 1,44$ & $3,00 \pm 1,43$ & $>0,05$ & $<0,01$ & $<0,01$ & $<0,05$ & $<0,01$ & $<0,01$ \\
\hline $\begin{array}{l}\text { Соціально-емоціi } \\
\text { підтримка }\end{array}$ & $6,54 \pm$ & $6,50 \pm 1,55$ & $5,49 \pm 2,04$ & $3,19 \pm 1,97$ & $>0,05$ & $<0,01$ & $<0,01$ & $<0,05$ & $<0,01$ & $<0,01$ \\
\hline $\begin{array}{l}\text { Громадська і службова } \\
\text { підтримка }\end{array}$ & $7,58 \pm 1,57$ & $7,91 \pm 1,12$ & $6,45 \pm 1,44$ & $4,88 \pm 1,65$ & $>0,05$ & $<0,01$ & $<0,01$ & $<0,01$ & $<0,01$ & $<0,01$ \\
\hline $\begin{array}{l}\text { Особистісна } \\
\text { реалізація }\end{array}$ & $4,33 \pm 1,24$ & $3,69 \pm 1,15$ & $2,91 \pm 1,22$ & $2,04 \pm 1,02$ & $<0,05$ & $<0,01$ & $<0,01$ & $<0,01$ & $<0,01$ & $<0,01$ \\
\hline Духовна реалізація & $5,52 \pm 1,91$ & $5,94 \pm 1,19$ & $4,96 \pm 1,45$ & $3,46 \pm$ & $>0,05$ & $<0,05$ & $<0,01$ & $<0,01$ & $<0,01$ & $<0,01$ \\
\hline $\begin{array}{l}\text { Загальне сприйняття } \\
\text { життя }\end{array}$ & $2,85 \pm 1,03$ & $2,38 \pm 0,83$ & $2,01 \pm 0,79$ & $1,66 \pm 0,56$ & $<0,05$ & $<0,01$ & $<0,01$ & $<0,05$ & $<0,01$ & $<0,01$ \\
\hline $\begin{array}{l}\text { Суб'єктивне } \\
\text { благополуччя/ } \\
\text { задоволеність } \\
\end{array}$ & $8,56 \pm 2,62$ & $8,75 \pm 2,09$ & $7,09 \pm 2,28$ & $5,27 \pm 1,67$ & $>0,05$ & $<0,01$ & $<0,01$ & $<0,01$ & $<0,01$ & $<0,01$ \\
\hline $\begin{array}{l}\text { Виконання соціальних } \\
\text { ролей }\end{array}$ & $17,17 \pm 4,93$ & $16,91 \pm 3,47$ & $14,09 \pm 3,64$ & $9,85 \pm 3,49$ & $>0,05$ & $<0,01$ & $<0,01$ & $<0,01$ & $<0,01$ & $<0,01$ \\
\hline $\begin{array}{l}\text { Зовнішні життєві } \\
\text { умови }\end{array}$ & $19,69 \pm 4,72$ & $20,34 \pm 3,10$ & $16,94 \pm 4,27$ & $11,54 \pm 4,84$ & $>0,05$ & $<0,01$ & $<0,01$ & $<0,01$ & $<0,01$ & $<0,01$ \\
\hline Сума балів & $45,42=$ & $46,00 \pm 7,90$ & $38,12 \pm 9,28$ & $26,66 \pm 9,34$ & $>0,05$ & $<0,01$ & $<0,01$ & $<0,01$ & $<0,01$ & $<0,01$ \\
\hline Показник якості життя & $4,54 \pm 1,19$ & $4,60 \pm 0,79$ & $3,81 \pm 0,93$ & $2,67 \pm 0,93$ & $>0,05$ & $<0,01$ & $<0,01$ & $<0,01$ & $<0,01$ & $<0,01$ \\
\hline
\end{tabular}

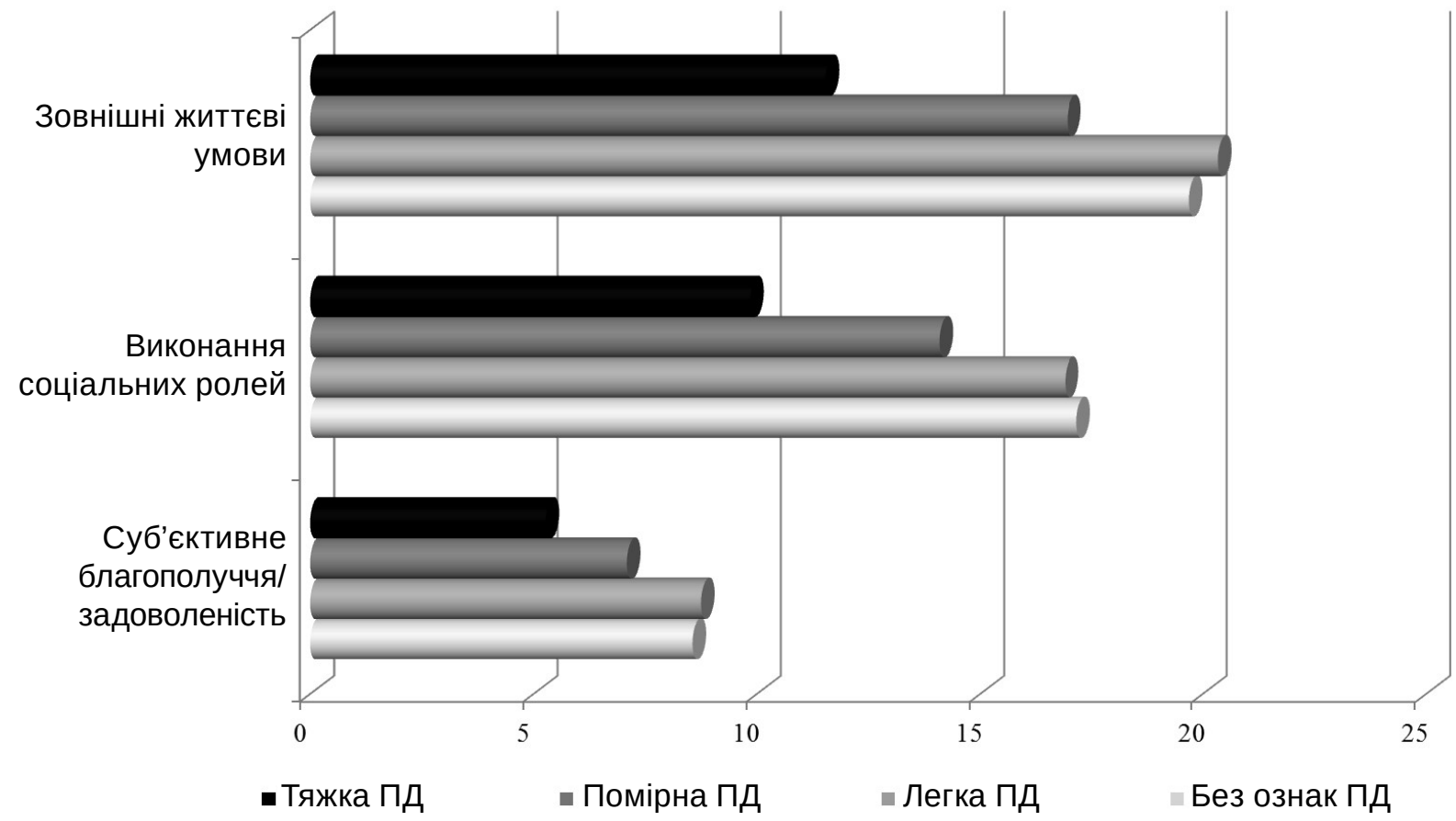

Puc. 7. Середні показники за основними сферами якості життя у жінок, хворих на депресивні розлади, з різними ступенями мікросоціальної дезадаптації. 


\section{Висновки}

У нашому дослідженні виявлено закономірності щодо погіршення ЯЖ за всіма сферами при зростанні тяжкості ПД в усіх сорерах життєдіяльності. Найбільше ці закономірності проявляються при МакПД, а найменше - при МікПД.
Перспективи подальших досліджень. Виявлені закономірності повинні враховувати при розробці лікувально-реабілітаційних заходів для хворих на депресивні розлади, що становить перспективу даної роботи.

\section{Список літератури}

1. Венгер О. П. Особливості якості життя емігрантів та реемігрантів, хворих на депресивні розлади / О. П. Венгер // Здобутки клінічної і експериментальної медицини. - 2016. - № 2. - С. 33-36.

2. Ісаков Р. І. Порівняльний аналіз вираженості психосоціальної дезадаптації й афективної симптоматики у жінок, хворих на депресивні розлади різного ґенезу / Р. І. Ісаков // Український вісник психоневрології. - 2018. - Т. 26, вип. 3 (96). - С. 20-26.

3. Ісаков Р. І. Психосоціальна дезадаптація у жінок з депресивними розладами різного ґенезу: особливості діагностики, вираженості і структури / Р. І. Ісаков // Психіатрія, неврологія, медична психологія. - 2018. - № 9. C. 82-92.

4. Критерий качества жизни в психиатрической практике / Н. А. Марута, Т. В. Панько, И. А. Явдак [и др.] ; под общ. ред. Н. А. Маруты. - Харьков : РИФ Арсис, ЛТД, 2004. - 240 с.

5. Матвієнко Ж. І. Особливості якості життя Хворих на депресивні розлади, що мешкають у сільській місцевості / Ж. І. Матвієнко // Нові підходи до діагностики, лікування та реабілітації психічних захворювань : матеріали наук.практ. конср. 3 міжнар. участю, 2010. - Харків. - 2010. - С. 318-320.

6. Новик А. А. Исследование качества жизни в медицине : учеб. пособ. / А. А. Новик, Т. И. Ионова. - М. : ГЭОТАРМЕД, 2004. - 304 C.

7. Чабан О. С. Якість життя пацієнта з позицій медичної психології / О. С. Чабан // Мистецтво лікування. - 2008. № 5 (51). - C. 40-43.

8. Katschnig H. Quality of life in mental disorders / H. Katschnig, H. Freeman, N. Sartorius. - New York: MPress, 2005. $368 \mathrm{p}$.

9. Staque M. J. Quality of Life assessment in clinical trials: monography / M. J. Staque. - Oxford, N.Y., Tokyo: Oxford University Press, 1998. - $360 \mathrm{p}$.

10. The WHOQOL Group. The World Health Organization Quality of Life Assessment (WHOQOL): Position Paper from the World Health Organization. Soc. Sci. Med. - 1995. - Vol. 41. - P. 1403-1409.

\section{References}

1. Venher, O.P. (2016). Osoblyvosti yakosti zhyttia emihrantiv ta reemihrantiv, khvorykh na depresyvni rozlady [Peculiarities of life quality of emigrants and re-emigrants with depressive Disorders]. Zdobutky klinichnoi $i$ eksperymentalnoi medytsyny - Achievements of Clinical and Experimental Medicine, 2, 33-36 [in Ukrainian].

2. Isakov, R.I. (2018). Porivnialnyi analiz vyrazhenosti psykhosotsialnoi dezadaptatsii i afektyvnoii symptomatyky u zhinok, khvorykh na depresyvni rozlady riznoho genezu [Comparative analysis of the severity of psychosocial maladaptation and affective symptomatology in women suffering from depressive disorders of different genesis]. Ukrayinskyi visnyk psykhonevrolohii - Ukrainian Journal of Psychoneurology, 26, 3 (96), 20-26 [in Ukrainian].

3. Isakov, R.I. (2018). Psykhosotsialna dezadaptatsiia u zhinok z depresyvnymy rozladamy riznoho genezu: osoblyvosti diahnostyky, vyrazhenosti i struktury [Psychosocial maladaptation in women with depressive disorders of different genesis: features of diagnosis, severity and structure]. Psykhiatriia, nevrolohiia, medychna psykholohia - Psychiatry, Neurology, Medical Psychology, 9, 82-92 [in Ukrainian].

4. Maruta, N.A., Panko, T.V., Yavdak, I.A., Semykina, Ye.Ye., Kolyadko, S.P., \& Kalenskaya, G.Yu. (2004). Kriteriy kachestva zhizni v psikhiatricheskoy praktike [Quality of life criterion in psychiatric practice]. Maruta, N.A. (Ed.). Kharkiv: RIF Arsis LTD [in Russian].

5. Matviyenko, Zh.I. (2010). Osoblyvosti yakosti zhyttia khvorykh na depresyvni rozlady, shcho meshkaiut u silskii mistsevosti [Features of the quality of life of patients with depressive disorders living in rural areas]. Mizhnarodna naukovo-praktychna konferentsiia "Novi pidkhody do diahnostyky, likuvannia ta reabilitatsii psykhichnykh zakhvoriuvan" - International Scientific and Practical Conference "New Approaches to the Diagnosis, Treatment, and Rehabilitation of Mental IIIness". Kharkiv (pp. 318-320) [in Ukrainian].

6. Novik, A.A., \& Ionova, T.I. (2004). Issledovaniye kachestva zhizni v meditsine: ucheb. posobiye [The study of the quality of life in medicine: textbook]. Moscow: GEOTAR-MEDIA [in Russian].

7. Chaban, O.S. (2008). Yakist zhyttia patsiienta z pozytsii medychnoi psykholohii [Quality of life of the patient from the standpoint of medical psychology]. Mystetstvo likuvannia - The Art of Healing, 5 (51). Retrieved from: http://www.healthmedix.com/articles/misteztvo/2008-06-15/40-43.pdf [in Ukrainian].

8. Katschnig, H., Freeman, H., \& Sartorius, N. (2005). Quality of life in mental disorders. New York: MPress.

9. Staque, M.J. (1998). Quality of Life assessment in clinical trials: monography. Oxford, N.Y., Tokyo: Oxford University Press.

10. The WHOQOL Group. (1995). The World Health Organization Quality of Life Assessment (WHOQOL): Position Paper from the World Health Organization. Soc. Sci. Med., 41, 1403-1409. 


\section{QUALITY OF LIFE IN WOMEN WITH DEPRESSION OF DIFFERENT GENESIS AND VARIOUS EXPRESSION OF MACRO-, MESO- AND MICROSOCIAL DISADAPATION}

\section{R. I. Isakov}

Ukrainian Medical Dental Academy, Poltava, Ukraine

Purpose: to study the quality of life in women with depression of different genesis and different severity of macro-, meso- and microsocial maladaptation, in order to determine further targeted aims of personalization of treatment and rehabilitation measures for this contingent of patients.

Materials and Methods. Contingent and research methods. 252 women with depressive disorders were examined: 94 persons with psychogenic (prolonged depressive response caused by adaptation disorder), 83 women with endogenous (depressive episode; recurrently depressive disorder; bipolar affective disorder; current episode of depression) and 75 with depression (organ depression) and 75 affective disorders). 48 women had no signs of psychosocial maladaptation, while the other 204 showed manifestations of macro-, meso-, and microsocial maladaptation of different severity. The study was conducted using clinical psychopathological and psychodiagnostic methods.

Results. As a result of the study, regularities were found to deteriorate the quality of life in all spheres as the severity of psychosocial maladaptation in all spheres of life increased. Most of these patterns are manifested in macrosocial maladaptation, and the smallest in microsocial maladaptation.

Conclusions. The identified patterns should be taken into account in the development of treatment and rehabilitation measures for patients with depressive disorders, which is the perspective of this work.

Key words: depressive disorders; psychosocial maladaptation; macro-, meso-microsocial maladaptation; psychogenic depression; organic depression; endogenous depression; women.

Рукопис надійшов до редакції 04.02.2020 p.

\section{Відомості про автора:}

Ісаков Рустам Ісроїлович - кандидат медичних наук, доцент, доцент кафедри психіатрії, наркології та медичної психології ВДНЗУ «Українська медична стоматологічна академія». 